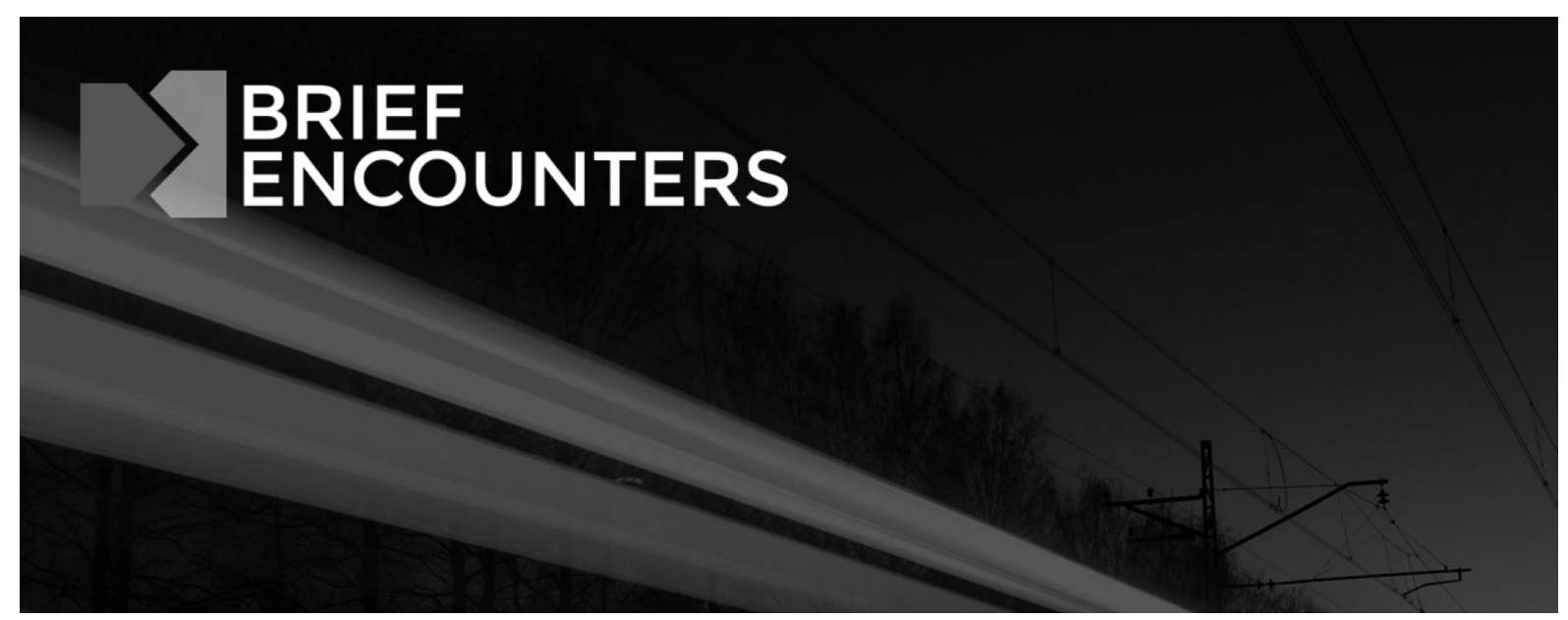

ISSN 2514-0612

Journal homepage: http://briefencounters-journal.co.uk/BE

The Many Ways to Count the World: Counting Terms in Indigenous Languages and Cultures of Rondônia, Brazil

Author(s): Vera Da Silva Sinha, Wany Sampaio, Christopher Sinha

Email:V.Da-Silva-Sinha@uea.ac.uk,wansamp@gmail.com,christopher.sinha@gmail.com

Source: Brief Encounters Vol.1, No. 1 (Feb 2017)

URL: http://briefencounters-journal.co.uk/BE/article/view/26/

DOI: http://dx.doi.org/10.24134/be.v1i1.26

(C) Vera Da Silva Sinha, Wany Sampaio, Christopher Sinha, 2017

License (open-access): This is an open-access article distributed under the terms of the Creative Commons Attribution License 4.0, which permits unrestricted use, distribution, and reproduction in any medium, provided the original work is properly cited. No warranty, express or implied, is given. Nor is any representation made that the contents will be complete or accurate or up to date. The publisher shall not be liable for any actions, claims, proceedings, demand or costs or damages whatsoever or howsoever caused arising directly or indirectly in connection with or arising out of the use of this material.

Brief Encounters is an open access journal that supports the dissemination of knowledge to a global readership. All articles are free to read and accessible to all with no registration required. For more information please visit our journal homepage: http://briefencounters-journal.co.uk/BE. 


\title{
The Many Ways to Count the World: Counting Terms in Indigenous Languages and Cultures of Rondônia, Brazil
}

\author{
Vera Da Silva Sinha, Wany Sampaio, Christopher Sinha
}

\section{Introduction}

Counting, measuring and quantifying the world are human practices that have attracted much scientific interest, in developmental psychology, in neuropsychology and in language acquisition studies. ${ }^{1}$ Our focus in this article is on cultural and linguistic variation, a topic that is receiving growing attention in this field. ${ }^{2}$ Our aim is to illustrate the cultural and linguistic diversity that exists in these practices by presenting the results of a survey of number systems and ways of counting in twenty-three indigenous languages spoken in the state of Rondônia, in North-Western Brazil.

\footnotetext{
1 Sue Ellen Antell and Daniel P. Keating, 'Perception of Numerical Invariance in Neonates', Child Development, 54.3 (1983), 695-701 <https:// doi.org/10.2307/1130057> [accessed 10 January 2016] (p. 695); C. R. Gallistel and Rochel Gelman, 'Preverbal and Verbal Counting and Computation', Cognition, 44.1-2 (1992), 43-74; F. Xu and E. S. Spelke, 'Large Number Discrimination in 6-Month-Old Infants', Cognition, 74.1 (2000), B1-11 Xu, F., and E. S. Spelke, 'Large Number Discrimination in 6-Month-Old Infants', Cognition, 74 (2000), B1-11 <https://doi.org/ 10.1016/S0010-0277(99)00066-9> [accessed 15 March 2015]; Steven W. Anderson, Antonio R. Damasio and Hanna Damasio, 'Troubled Letters but Not Numbers: Domain Specific Cognitive Impairments Following Focal Damage in Frontal Cortex', Brain, 113.3 (1990), 749-766 <https:// doi.org/10.1093/brain/113.3.749> [accessed 10 January 2016]; Brian Butterworth, The Mathematical Brain (London: Macmillan, 1999); Tetsuro Matsuzawa, 'Use of Numbers by a Chimpanzee', Nature, 315.6014 (1985), 57-59 <https://doi.org/10.1038/315057a0> [accessed 24 July 2016 ] (p. 57), cited by Rafael E. Núñez, 'No Innate Number Line in the Human Brain', Journal of Cross-Cultural Psychology, 42.4 (2011), 651-668 <https://doi.org/10.1177/0022022111406097> [accessed 15 March 2015] (p. 651); Barbara W. Sarnecka and Susan Carey, 'How Counting Represents Number: What Children Must Learn and When They Learn It', Cognition, 108.3 (2008), 662-674 <https://doi.org/10.1016/ j.cognition.2008.05.007> [accessed 15 March 2015].

2 Rafael Núñez, Kensy Cooperrider and Jürg Wassmann, 'Number Concepts without Number Lines in an Indigenous Group of Papua New Guinea', PloS One, 7.4 (2012), e35662-e35662 <https://doi.org/10.1371/journal.pone.0035662> [accessed 15 March 2015]; Núñez, 'No Innate Number Line in the Human Brain', pp. 651-668; Stanislas Dehaene, Véronique Izard, Elizabeth Spelke and Pierre Pica, 'Log or Linear? Distinct Intuitions of the Number Scale in Western and Amazonian Indigene Cultures', Science, 320.5880 (2008), 1217-1220; Véronique Izard, Pierre Pica, Elizabeth Spelke and Stanislas Dehaene, 'Exact Equality and Successor Function: Two Key Concepts on the Path towards Understanding Exact Numbers', Philosophical Psychology, 21.4 (2008), 491-491 <https://doi.org/10.1080/09515080802285354> [accessed 24 July 2016]; Peter Gordon, 'Numerical Cognition without Words: Evidence from Amazonia', Science, 306.5695 (2004), 496-499 <https:// doi.org/10.1126/science.1094492> [accessed 10 March 2015] (p. 496); Diana Green, 'O sistema numérico da língua palikúr', Boletim do Museu Paraense Emílio Goeldi, Série Antropologia e Linguística (1994) <http://www.pnglanguages.org/americas/brasil/publcns/ling/ PortPLNB.pdf> [accessed 24 July 2016]; Diana Green, 'Diferenças entre termos numéricos em algumas línguas indígenas do Brasil', Boletim do Museu Paraense Emílio Goeldi, Série Antropologia e Linguística (1997) <http://www.unifal-mg.edu.br/matematica/files/file/ANDREA/ Historia/termos\%20numericos\%20indigenas\%20brasil.pdf> [accessed 24 July 2016]; Pierre Pica and Alain Lecomte, 'Theoretical Implications of the Study of Numbers and Numerals in Mundurucu', Philosophical Psychology, 21.4 (2008), 507-522; Pierre Pica, Cathy Lemer, Véronique Izard and Stanislas Dehaene, 'Exact and Approximate Arithmetic in an Amazonian Indigene Group', Science, 306.5695 (2004), 499-502 <https://doi.org/10.1126/science.1102085> [accessed 15 March 2015]; Jürg Wassmann and P. Dasen, 'Yupno Number System and Counting', Journal of Cross-Cultural Psychology, 25 (1994), 78-94.
} 
There have been a number of previous studies of counting systems of Brazilian indigenous peoples that can serve to highlight the diversity of these, including the Pirahã or Hiaitsilhi, the Mundurucu and the Palikur. ${ }^{3}$ The Pirahã employ terms seemingly equivalent to 'one', 'two' and 'many' but the terms one and two do not, it seems, reflect strict numerical value. ${ }^{4}$ The Mundurucu linguistic counting term system consists of: more or less one; more or less two; more or less three; more or less four; and a handful, which is about five. The Mundurucu, like many other peoples, also use parts of the body as a reference for counting and measuring. ${ }^{5}$ This apparent simplicity of the Pirahã and Munduru counting systems can be contrasted with the complexity of Palikur:

In the Palikur tongue, many numerals from 1 to 199 present affixes that qualify the noun or the verb to which the numeral refers to. Fixed at the root of all numerical terms one can see one of the twenty numerical classifiers, distinct morphemes that deal with whole individual units, sets, fractions, abstract ideas and series. The term for the numeral 1 agrees in gender with animate units. The inanimate units are classified according to their geometric shapes. The numerical terms can receive nine distinct inflections which refer to arithmetical concepts such as numerical sequence, addition, subtraction, more or less, multiplication, totality and several sets. The numerical terms function not only as adjectives, but also as adverbs, pronouns, verbs and nouns, with all appropriate grammatical inflections for the syntactic function that they perform. ${ }^{6}$

\footnotetext{
3 The Pirahã or Hiaitsilhi are an indigenous society living in the lands by the rivers Marmelo and Maici, in Humaitá, state of Amazonas; they speak the language Apaitsiis. See Curt Nimuendajú, 'The Mura and Pirahã', in Handbook of South American Indians, ed. by Julian H. Steward (Washington: Smithsonian Institution, 1948), pp. 255-269. The Mundurucu are an indigenous society living in different regions in the states of Pará (southwest, a branch of the Tapajós River, in the municipalities of Santarém, Itaituba, Jacareacanga); Amazonas (East, Canumã River, municipality of Nova Olinda, and near the Transamazonica Highway in the municipality of Borba); and Mato Grosso (North, Region of the Rio dos Peixes, municipality of Juara). Most of the population lives in Mundurucu Indigenous Land, distributed in different villages, located along the river Cururu, a branch of the Tapajos river. The population is about 7,000 people; they speak the Mundurucu language, which belongs to the Tupi language family. The Palikur are an indigenous society living in the region of Amapá; they speak the language Palikúr.

${ }^{4}$ Michael C. Frank, Daniel L. Everett, Evelina Fedorenko and Edward Gibson, 'Number as a Cognitive Technology: Evidence from Pirahã Language and Cognition', Cognition, 108.3 (2008), 819-824; Daniel L. Everett, 'Cultural Constraints on Grammar and Cognition in 'Pirahã: Another Look at the Design Features of Human Language', Current Anthropology, 46.4 (2005), 621-646; Gordon, pp. 496-499 <https:// doi.org/10.1086/431525> [accessed 10 January 2016].

5 Dehaene and others, 'Log or Linear?', pp. 1217-1220; Pica and others, 'Exact and Approximate Arithmetic in an Amazonian Indigene Group', p. 499. ${ }^{6}$ Green, 'O sistema numérico da língua palikúr', p. 1. Quotation translated by the authors.
} 
Diana Green presents a linguistic description of numerical terms in over forty indigenous

Brazilian languages, highlighting the differences between the systems that are based on the numbers one, two, three, five, ten, and twenty:

Systems based on one and two present a limited number terminology rarely exceeding the numeral 6 , while languages with systems based on 10 and 20 present a larger terminology, sometimes over one hundred. Numerical terms of the systems based on 1 or 2 indicate a relational and global reasoning; the others demonstrate an analytical and synthetic reasoning. In many indigenous languages with numerical terminology based on 10 or 20, the terms present very complex inflections. But all these systems are highly logical and appropriate to the needs of the people who use them. ${ }^{7}$

Our aim in this study is to document variation and similarity in the counting systems of diverse languages spoken in the geographical area delimited by the Brazilian state of Rondônia.

\section{Method and Results}

During 2012 two of the authors worked with indigenous teachers from twenty-four linguistic and cultural communities residing in Rondônia state, as part of the Açaí Project, an in-service training course focused on indigenous languages and their description, as well as intercultural communication and mother tongue education. ${ }^{8}$ The language of instruction of the inservice course was Portuguese. As part of this work, we conducted together with the indigenous teachers an investigation of the terminology of counting, each teacher producing a list of numerical terms employed in their native language. ${ }^{9}$ All the teachers who participated in this study were bilingual in Portuguese and in their indigenous mother tongue, and some spoke more than one indigenous language. One teacher had to return to their village during

\footnotetext{
7 Green, 'Diferenças entre termos numéricos em algumas línguas indígenas do Brasil', p. 1. Quotation translated by the authors.

8 Projeto Açaí is a training program for indigenous teachers initiated by the Secretary of Education of the State of Rondônia, Brazil. The Açaí Project provides in-service education for indigenous primary and secondary school teachers, qualifying them to work in indigenous schools in the first four grades of primary and secondary schooling. Each course has a duration of four years, divided into eight stages. In 2012 , the project was in its third edition and at that time had trained more than three hundred indigenous teachers.

9 We emphasise that the teachers wrote the list using their own handwriting and spelling conventions, therefore there may be discrepancies in relation to published reports by non-indigenous researchers.
} 
the course, so below we present data from twenty-three languages, from seven distinct language families, including three linguistic isolates. ${ }^{10}$ The largest family of indigenous languages of South America is the Tupi branch or macro-family, to which eleven of the languages in our sample belong, representing six different Tupian language sub-families. The other languages in the sample were members of the Pano, Nambikwara and Xapakura families, along with three linguistic isolates.

In Tables 1 and 2 below, we list the numerical vocabulary according to the information supplied by the indigenous teachers. ${ }^{11}$ To facilitate comparison, we have grouped the Tupian language families in Table 1 and the other families in Table 2.

Table 1. Counting Terms in the Tupian Languages

\begin{tabular}{|c|l|l|l|l|l|}
\hline & \multicolumn{2}{|c|}{ TUPI-GUARANI (Kawahib) } & \multicolumn{2}{c|}{ TUPARI } & PURUBORÁ \\
\hline & Amondawa & Uru-eu-uau-uau & Tupari & Makurap & Puruborá \\
\hline 1 & Ape'i & Ape'i & Kiem & Erea & Mũ \\
\hline 2 & Monkõi & Monkõi & Huru & Erea érea & Ewap \\
\hline 3 & Monkongaturaipei & Monkongaturaipei & Huruno'on & Erekut & Mũ ewap \\
\hline 4 & Monkongatumeme & Monkongatumeme & Huru huru & & \\
\hline 5 & Monkongatumemeape'i & Monkongatumemeape'i & & & Dede \\
\hline Muitos & E'ui & E'ui & & \\
\hline & Karitiana (TUPI-ARIKÉM) & & Arara (TUPI-RAMA-RAMA) & \\
\hline 1 & Myhint & Kot̃ & \\
\hline 2 & Sypomp & Xagarokõm & \\
\hline 3 & Mỹ̃mp & Pag̃ontop & \\
\hline 4 & Otadnamynt & Pag̃otopãt & Pag̃opaypãt \\
\hline 5 & Yjpyt & Pag̃onopaypãt & \\
\hline 6 & Myhint yjpy otaot & Sypomp yjpy otaot & Pag̃anopaypãy & \\
\hline 8 & Myj̃mp yjpy otaot & & \\
\hline
\end{tabular}

$10 \mathrm{~A}$ linguistic isolate (isolated language) is a language with no known extant genetically related language.

11 Tables 1 and 2 were prepared by the authors using the linguistic classifications of Aryon Dall'Igna Rodrigues and Ana Suelly Arruda Câmara Cabral, 'Tupían', in The Indigenous Languages of South America: A Comprehensive Guide, ed. by Lyle Campbell and Verónica Grondona (Berlin: De Gruyter Mouton, 2012), pp. 495-574; Dietrich Wolf, 'O tronco tupi e as suas famílias de línguas. Classificação e esboço tipológico', in O Português e o Tupi no Brasil, ed. by Wolf Dietrich and Volker Noll (São Paulo: Editora Contexto, 2010), pp. 9-26. 


\begin{tabular}{|c|c|c|c|c|c|}
\hline 9 & \multicolumn{2}{|l|}{ Otadnamynt yjpy otaot } & \multicolumn{3}{|l|}{ Pag̃ontopaytop } \\
\hline 10 & \multicolumn{2}{|l|}{ Yjpy ota tyytap } & \multicolumn{3}{|l|}{ Pa'pík } \\
\hline 11 & \multicolumn{2}{|l|}{ Myhint yjpi opỹ ot } & & & \\
\hline 12 & \multicolumn{2}{|l|}{ Sypomp yjpi opỹ } & & & \\
\hline 13 & \multicolumn{2}{|l|}{ Myjymp yjpi opỹ } & & & \\
\hline 14 & \multicolumn{2}{|l|}{ Otadnamynt yjpi opỹ ot } & & & \\
\hline 15 & \multicolumn{2}{|l|}{ Yjpyt yjpi opỹ ot } & & & \\
\hline 16 & \multicolumn{2}{|l|}{ Myhint yjpi opỹ otaot } & & & \\
\hline 17 & \multicolumn{2}{|l|}{ Sypomp yjpi opỹ otaot } & & & \\
\hline 18 & \multicolumn{2}{|l|}{ Myj̃ymp yjpi opỹ otaot } & & & \\
\hline 19 & \multicolumn{2}{|l|}{ Otadnamynt yipi opỹ otaot } & & & \\
\hline 20 & \multicolumn{2}{|l|}{ Yjmyhin pi pyyk } & & & \\
\hline Muitos & \multicolumn{2}{|l|}{ Kandat } & & & \\
\hline \multicolumn{6}{|c|}{ TUPI- MONDÉ } \\
\hline & Gavião & \multicolumn{2}{|c|}{ Suruí } & Cinta-Larga & Aruá \\
\hline 0 & & \multicolumn{2}{|l|}{ So õb } & Pirum & \\
\hline 1 & Móhj & \multicolumn{2}{|l|}{ Muy } & Muuj & Mon \\
\hline 2 & Pàhdjakúhv & \multicolumn{2}{|l|}{ Xakalar } & Busyyt & Bosá \\
\hline 3 & Àsáno óhv & \multicolumn{2}{|l|}{ Xakalar amakab õb } & Busyyt'muuj & Bosá retet \\
\hline 4 & Àsáno pír & \multicolumn{2}{|l|}{ Xalar itxer } & Xisaj'pitpareteet & Bosá bosá \\
\hline 5 & Móhj pábe & \multicolumn{2}{|l|}{ Muy pamabeh } & Muujpabe & Werep \\
\hline 6 & Móhj ma’á má pábe pí mán & \multicolumn{2}{|c|}{ Muy pamabeh pih muy txor } & Muujpabe'muuj & \\
\hline 7 & $\begin{array}{l}\text { Pàhdjakúhv ma'á má pábe pí } \\
\text { mán }\end{array}$ & \multicolumn{2}{|c|}{ Muy pamabeh pih xakalar } & & \\
\hline 8 & $\begin{array}{l}\text { Àsáno óhva mán ma'á má } \\
\text { pábe pí mán }\end{array}$ & \multicolumn{2}{|c|}{ Muy pamabeh pih xakalar amakab õb } & & \\
\hline 9 & $\begin{array}{l}\text { Àsáno pírá mán ma’á má pábe } \\
\text { pí mán }\end{array}$ & \multicolumn{2}{|c|}{ Muy pamabeh pih xakalar itxer } & & \\
\hline 10 & Pabábe sópov & \multicolumn{2}{|l|}{ Baga pamabeh } & & Werep werep \\
\hline 11 & & \multicolumn{2}{|c|}{ Baga pamabeh de pih muy txor } & & \\
\hline 12 & & Baga pamabeh deh & xakalar & & \\
\hline 13 & & $\begin{array}{l}\text { Baga pamabeh deh } \\
\text { õb }\end{array}$ & xakalar amakab & & \\
\hline 14 & & Baga pamabeh deh & xakalar itxer & & \\
\hline 15 & & Baga pamabeh deh & muy xakalar & & \\
\hline $\begin{array}{l}\text { Muito } \\
\mathrm{s}\end{array}$ & Gólóá & Xameomi & & Ngulua & \\
\hline
\end{tabular}

Source: Prepared by the authors from data provided by the indigenous teachers of the Açaí Project (2012). 
Table 2. Counting Terms in the Pano, Nambikwara, Xapakura and Isolated Languages

\begin{tabular}{|c|c|c|c|c|c|c|c|}
\hline & & 1 & 2 & 3 & 4 & 5 & Lot \\
\hline Pano & Kaxarari & Wyspi & Tshabyta & Tshabyta wyspi & Tshabyta tshabyta & Wyspi mykyly & Wabihani \\
\hline \multirow{2}{*}{$\begin{array}{l}\text { Nambi } \\
\text { Kuara }\end{array}$} & Latundê & Kãnãna & Bãna & Bãkãnãná & Bãĩbãĩ & & Wayná \\
\hline & Mamaindê & Ka'nãga & Ba’nĩ & Ba'kanãnga & Ba'nĩ-ba'nĩ & Hi'gahãlatwa & $\begin{array}{l}\text { Ka'nilatw } \\
\text { a }\end{array}$ \\
\hline \multirow{6}{*}{ Xapakura } & Oro Mon & $\begin{array}{l}\text { Xicapen } \\
\text { a }\end{array}$ & $\begin{array}{l}\text { Horoman'tocon } \\
\text { a }\end{array}$ & Tocwan'ma & Paritona & Irimiyona & \\
\hline & Oro Não & $\begin{array}{l}\text { Xicapen } \\
\text { a }\end{array}$ & $\begin{array}{l}\text { Horoman'tocon } \\
\text { a }\end{array}$ & Tocwan'ma & Paritona & Irimiyona & \\
\hline & Oro Eo & $\begin{array}{l}\text { Xicapen } \\
\text { a }\end{array}$ & $\begin{array}{l}\text { Horoman'tocon } \\
\text { a }\end{array}$ & Tocwan'ma & Paritona & Irimiyona & \\
\hline & Oro Win & $\begin{array}{l}\text { Kawasa } \\
\mathrm{n}\end{array}$ & loksan & & & & Miyana \\
\hline & Oro Waram & $\begin{array}{l}\text { Xikapen } \\
\text { a }\end{array}$ & Tokana & & & & \\
\hline & $\begin{array}{l}\text { Oro Waram } \\
\text { Xijen }\end{array}$ & $\begin{array}{l}\text { Xikapen } \\
\text { a }\end{array}$ & $\begin{array}{l}\text { Horoman'tocon } \\
\text { a }\end{array}$ & Tocwan'ma & Paritona & Irimiyona & Miyana \\
\hline \multicolumn{8}{|c|}{ ISOLATED LANGUAGES } \\
\hline & \multicolumn{3}{|l|}{ Canoé } & \multicolumn{2}{|l|}{ Aikanã } & \multicolumn{2}{|c|}{$\begin{array}{l}\text { Jabuti (Jeromitxi) } \\
\text { (Macro-Jê family?) }\end{array}$} \\
\hline 1 & \multicolumn{3}{|l|}{ Pja dokere } & \multicolumn{2}{|l|}{ Amẽmẽ } & \multicolumn{2}{|c|}{ Uitxi } \\
\hline 2 & \multicolumn{3}{|l|}{ Mõw } & \multicolumn{2}{|l|}{ Atuca } & \multicolumn{2}{|c|}{ Djebo } \\
\hline 3 & \multicolumn{3}{|l|}{ Mõw pja } & \multicolumn{2}{|c|}{ Atuca amẽmẽ } & \multicolumn{2}{|l|}{ Djebo honotõ } \\
\hline 4 & \multicolumn{3}{|l|}{ Mõw mõw } & \multicolumn{2}{|c|}{ Atuca atuca } & \multicolumn{2}{|l|}{ Djebo djebo } \\
\hline 5 & \multicolumn{3}{|c|}{ Mõw mõw pja } & \multicolumn{2}{|c|}{ Atuca atuca amẽmẽ } & \multicolumn{2}{|c|}{ Djebo djebo honotõ } \\
\hline 6 & \multicolumn{3}{|c|}{ Mõw mõw mõw } & & & & \\
\hline 7 & \multicolumn{3}{|c|}{ Mõw mõw mõw pja } & & & & \\
\hline 8 & \multicolumn{3}{|c|}{ Mõw mõw mõw mõw } & & & & \\
\hline 9 & \multicolumn{3}{|c|}{ Mõw mõw mõw mõw pja } & & & & \\
\hline 10 & Mõw itso & & & & & & \\
\hline 11 & Mõw itso & & & & & & \\
\hline 12 & Mõw itso & nõw & & & & & \\
\hline 15 & Mõw itso & ja itsotsi & & & & & \\
\hline 20 & Mõw itso & nõw itsot & & & & & \\
\hline Muitos & & & & & & Uitxitõ txuni & \\
\hline
\end{tabular}

Source: Prepared by the authors from data provided by the indigenous teachers of the Açaí Project (2012). 


\section{Discussion}

We can observe the following from the data presented in Tables 1 and 2:

(i) The number of 'basic', single-word counting terms ranges from one or two (Makarup) to five, or six if we include the term for 'none'. Other counting terms are derived from the combination of these terms, including through reduplication and/or morphological inflection.

(ii) The counting sequences have ranges (expressed numerically) from three to at least twenty; some languages seem to have no limits on the number of terms or complex expressions used to count; in these languages the countable 'numbers' are expressed by distinct lexemes denoting the terms from one and/or zero to five, and combinations of them.

(iii) Makurap is the 'smallest number' language with terms corresponding to one, two and three, the term for two being formed by reduplication of 'one' and the term for three probably also being derived from 'one'. Two Xapacura languages (Oro Win and Oro Wara) are reported as having only two numbers, but this may be because the speakers did not know the other numbers, since all other closely related Xapacura languages had five attested numbers.

(iv) Most of the languages have lexically distinct terms for one and two; these words can be combined, allowing for counting to three, four, five or more, based on a compounding process (by juxtaposition, agglutination or reduplication). After that things are quantified by a term that apparently means many or a lot. This general pattern holds for the following languages: Amondawa (5); Uru-eu-waw-waw (5); Tupari (4); Puruborá (3); Kaxarari (5); Latundê (4); Mamaindê (4, with a different word for 5); Canoé (9, with a new word combination for ten to twenty); Aikanã (5). Jaboti (Djeoromitxi) has words for one, two and three, and the terms until five are formed by reduplication. 
(v) The Aruá language has distinct lexicalisations for one, two, three and five; the term for four is the reduplication of two and the term for ten is the reduplication of five.

(vi) The Arara language features specific words for one, two and three; the words from four to nine are formed from the word 'three' plus combined and/or reduplicated suffixes; for the word ten there is a different suffix.

(vii) The Xapacura languages have terms to indicate different amounts from one to five and thereafter they use the quantifier 'many' (see iii above).

(viii) The Karitiana language has terms to indicate different amounts from one to five; after this there are combinations up to twenty or more..$^{12}$

(ix) The Surui and Cinta Larga languages (Tupi Mondé) have terms for zero (or none) to three; thereafter introducing new terms and/or repeating words already introduced in combinations, in the Surui case up to fifteen or more. Although the Cinta Larga listed inventory ends at number six, according to one participant, 'the numbers expand $[. .$.$] we can count until twenty and so on it is too large to write [\ldots]$ there are more numerals. ${ }^{13}$

(x) The Gavião language has terms from one to three, with combinations to five, after which complex expressions are used to count from six to ten or more.

\footnotetext{
12 Ana Müller, Luciana Storto and Thiago Coutinho-Silva, 'Number and the Count-Mass Distinction in Karitiana', University of British Columbia Papers in Linguistics - UBCWPL 19: Proceedings of the Eleventh Workshop on Structure and Constituency in Languages of the Americas (2006), 122-135

13 Cinta-Larga Teacher, Acai Project, 2012.
} 


\section{Analysis of Patterns of Lexicalisation and Formation of Counting Terms}

Table 3 shows the lexicalisation patterns for all twenty-three languages that we have analysed. The notations L1-L5 stand for distinct, uninflected single-word lexical items that represent 'numbers' from one to five, and the notation $m$ stands for morphological modification. The strings in the columns headed 1-5 show how the count terms for one to five are derived from the single-word lexical items.

Table 3. Lexicalisation Patterns for Number in $\mathbf{2 3}$ Indigenous Languages of Rondônia

\begin{tabular}{|c|c|c|c|c|c|c|c|c|}
\hline Pattern & 1 & 2 & 3 & 4 & 5 & $\begin{array}{c}\text { No. of } \\
\text { attested } \\
\text { counting } \\
\text { terms (N) }\end{array}$ & $\begin{array}{l}\text { No. of } \\
\text { languages } \\
\text { with this } \\
\text { pattern (N) }\end{array}$ & $\begin{array}{c}\text { Family } \\
\text { (languages) }\end{array}$ \\
\hline A & L1 & L1 L1 & L3 (L1m?) & & & 3 & 1 & $\begin{array}{l}\text { Tupi-Tupari } \\
\text { (Makurap) }\end{array}$ \\
\hline B & L1 & L2 & L1 L2 & & & 3 & 1 & $\begin{array}{c}\text { Tupi Puruborá } \\
\text { (Puruborá) }\end{array}$ \\
\hline C & L1 & L2 & $\mathrm{L} 2 \mathrm{~m}$ & L2 L2 & & 4 & 1 & $\begin{array}{c}\text { Tupi-Tupari } \\
\text { (Tupari) }\end{array}$ \\
\hline D & L1 & L2 & $\begin{array}{l}\text { L2m.L1 } \\
(2+1)\end{array}$ & $\begin{array}{l}\mathrm{L} 2 \mathrm{~m} \\
(2 \times 2)\end{array}$ & $\begin{array}{c}\text { L2m.L1 } \\
((2 \times 2)+1)\end{array}$ & 5 & 2 & $\begin{array}{c}\text { Tupi Guarani } \\
\text { [Kawahib] } \\
\text { (Amondawa, } \\
\text { Uru-eu-uau- } \\
\text { uau) }\end{array}$ \\
\hline E & L1 & L2 & L2 L3 & L2 L2 & L5 & 5 & 1 & $\begin{array}{c}\text { Tupi-Mondé } \\
\text { (Aruá) }\end{array}$ \\
\hline $\mathrm{F}$ & L1 & L2 & L2 L1 & L2 L2 & $\begin{array}{l}\text { L1 L3 } \\
\text { (one } \\
\text { hand?) }\end{array}$ & 5 & 1 & Pano (Kaxarari) \\
\hline G & L1 & L2 & L2 L3 & L2 L2 & L2 L2 L3 & 5 & 1 & $\begin{array}{c}\text { Isolate } \\
\text { (Macro-Jê ?) } \\
\text { Jabuti } \\
\text { (Arikapú / } \\
\text { Jeromitxí) }\end{array}$ \\
\hline $\mathrm{H}$ & L1 & L2 & $\begin{array}{c}\text { L3 } \\
\text { (L2.L1?) }\end{array}$ & L2 L2 & L5 & 5 & 2 & $\begin{array}{l}\text { Nambikuara } \\
\text { (Latundê, } \\
\text { Mamaindê) }\end{array}$ \\
\hline
\end{tabular}




\begin{tabular}{|c|c|c|c|c|c|c|c|c|}
\hline 1 & L1 & L2 & $\mathrm{L} 2 \mathrm{~m}$ & L4 & L5 & 6 & 1 & $\begin{array}{l}\text { Tupi-Mondé } \\
\text { (Cinta Larga) }\end{array}$ \\
\hline J & L1 & L2 & L3(m?) & L3+ & L3+ & 10 & 1 & $\begin{array}{l}\text { Tupi-Rama- } \\
\text { Rama (Arara) }\end{array}$ \\
\hline K & L1 & L2 & $\mathrm{L} 2 \mathrm{~mm}$ & L3 & $\begin{array}{l}\text { L1 L5 } \\
\text { (one } \\
\text { hand?) }\end{array}$ & 16 incl. 0 & 1 & $\begin{array}{l}\text { Tupi-Mondé } \\
\text { (Surui) }\end{array}$ \\
\hline $\mathrm{L}$ & L1 & L2 & L3 L3 (?) & L3 L4 (?) & $\begin{array}{c}\text { L1 L5 } \\
\text { (one } \\
\text { hand?) }\end{array}$ & 10 & 1 & $\begin{array}{c}\text { Tupi-Mondé } \\
\text { (Gavião) }\end{array}$ \\
\hline M & L1 (L1) & L2 & L2 L1 & L2 L2 & L2 L2 L1 & $5-20$ & 2 & $\begin{array}{c}\text { Isolates } \\
\text { (Aikanã, Canoé) }\end{array}$ \\
\hline $\mathrm{N}$ & L1 & L2 & L3 & L4 & L5 & 5,20 & 5 & $\begin{array}{c}\text { Xapacura (Oro } \\
\text { Mon, Oro Não, } \\
\text { Oro Eo, Oro } \\
\text { Waram Xijen) } \\
\text { Tupi-Arikém } \\
\text { (Karitiana) }\end{array}$ \\
\hline 0 & L1 & L2 & & & & $2^{*}$ & $2 *$ & $\begin{array}{l}\text { Xapacura* } \\
\text { (Oro Win } \\
\text { Oro Waram) }\end{array}$ \\
\hline
\end{tabular}

Source: Prepared by the authors from data provided by the indigenous teachers of the Açaí Project (2012).

* The absence of numbers greater than 2 for these two languages may be a result of the speakers not knowing them, since all other Xapacura languages had 5 attested numbers.

There are ten distinguishable patterns (A to O) for forming counting terms. In general, particular patterns are shared by closely related languages, but not all related languages share the same patterns, and one pattern $(\mathrm{N})$ is shared by two unrelated languages. Standing back from the detail a little, the data shows two main commonalities between the different languages. First, as we have stated above, there is a restricted number (less than five) in each language of 'basic', single word counting terms, used to signify quantities from one (or in some cases 'none') to five. Second, we can note the productive use of these terms by combining them in different ways to refer to larger quantities. The counting terms form a linguistic quantificational system in each language, but this is not in most or all cases a number system; if by this is meant a system with an arithmetical base generating an 
indefinitely large set of numbers. Since this general pattern, and the variants of it, hold for both related and unrelated languages, it might be considered to be evidence of a way of thinking about and practicing quantification that is shared across a cultural area. ${ }^{14}$

Within this common framework, we can also observe distinct and diverse ways of counting, not only involving (as we would expect) different words in different languages, but also different numbers of words and different ways of organising the counting terms.

\section{Methodological Issues and Objections}

There are two principal methodological issues that may have impacted upon the reliability of the data that we report here. Firstly, the languages in our sample are all to a greater or lesser extent endangered, under threat from the national language, Portuguese. The teachers who provided the data are in many cases from a younger generation that has grown up in a context in which Portuguese is a salient part of the language environment. They may not have the same exhaustive knowledge of their native languages as older speakers, a fact that they acknowledged. All of our language consultants attested that they believed the data they provided on counting systems was accurate and, in most cases, with the exception of Cinta Larga (Discussion, point ix), complete. However, we cannot be sure of this, and we have also noted in relation to two Xapacura languages that there may be some doubt about the completeness of the data due to limited speaker knowledge (Discussion, point iii).

The second, related, issue is that all of the teachers were familiar with the Portuguese number system, indeed their familiarity with this was a pre-requisite for them being able to fill out the questionnaire. It could be argued that this knowledge interfered with their production of their counting systems. However, we do not consider this to have been the

\footnotetext{
14 The notion of cultural area is usually attributed to the early twentieth-century anthropologist Franz Boas, who argued against cultural and racial evolutionism and is generally credited with the postulation of cultural relativism as a methodological principle for cultural anthropology. We do not have space here to explore the notion of cultural area, its possible application to Amazonia and its relation to other current research in greater detail, see Alf Hornborg, 'Ethnogenesis, Regional Integration, and Ecology in Prehistoric Amazonia: Toward a System Perspective', Current Anthropology, 4.4 (2005), 589-607 <https://doi.org/10.1086/431530> [accessed 24 July 2016] (p. 589).
} 
case, since the reported lexicalisations bore no relation to the Portuguese lexicalisations. More problematic is the possibility that the counting systems themselves have been affected at a conceptual level, before their learning by the teachers, by the Portuguese decimal number system. We cannot exclude this possibility, but we would note that number systems based upon the ten digits of the two hands are common in the world's languages, so there is no reason to suppose that, for example, the ten lexemes of Arara (see Table 1) are derived either morphologically or conceptually from Portuguese.

\section{Conclusion}

Our survey of counting term systems in the indigenous languages of Rondônia has confirmed that the counting term systems of Amazonian languages are typically 'small', if we simply focus on the number of 'basic', single-word counting terms, and the fact that these represent quantities only up to a maximum of five. The data we present may add some weight to the argument that quantities less than five are especially perceptually salient and hence highly linguistically encodable. ${ }^{15}$ However, we should not allow this generalisation to obscure the equally important fact that these simple or basic counting terms are frequently employed productively to denote larger quantities, in some cases indefinitely larger. Furthermore, the patterns of lexicalisation and combination vary significantly between languages, giving rise to a highly diverse set of counting term systems, all based on similar general principles. These general principles, we hypothesise, are derived not from the formalization of the counting systems as number systems, in the strict sense, but from a common way of life and the particular place in that way of life of quantificational practices.

Our data and analyses support the contention of Diana Green that 'all these systems are highly logical and appropriate to the needs of the people who use them', suggesting that

\footnotetext{
15 James R. Hurford, 'Languages Treat 1-4 Specially', Mind \& Language, 16.1 (2001), 69-75 <https://doi.org/10.1111/1468-0017.00157>
} [accessed 24 July 2016] (p. 69). 
a deeper understanding of indigenous Amazonian counting term systems requires further research into the way they are used by community members in counting and other practices involving quantification. ${ }^{16}$ In this article, we have focused exclusively on the linguistic terms, and the way in which these are organised into systems. We shall report in a future article an ethnographic, practice-based analysis of the use of counting terms in one indigenous community of Rondônia, situating the lexical analysis in the context of everyday quantificational practices, including the use of other linguistic resources. Future research will enhance further the interdisciplinary dimension of this study exploring the wider linguistic, cultural and cognitive corollaries of our hypothesis that commonalities in Amazonian counting systems and quantificational practices are indicative of a Boasian cultural area.

${ }^{16}$ Green, 'Diferenças entre termos numéricos em algumas línguas indígenas do Brasil', p. 1. 


\section{Acknowledgements}

We wish to thank the indigenous student teacher participants of the Açai Project (2012) for teaching us how they count in their languages. 


\section{Bibliography}

Anderson, Steven W., Antonio R. Damasio, and Hanna Damasio, 'Troubled Letters but not Numbers: Domain Specific Cognitive Impairments Following Focal Damage in Frontal Cortex', Brain, 113 (1990), 749-766 <https://doi.org/10.1093/brain/113.3.749> [accessed 10 January 2016]

Antell, Sue Ellen, and Daniel P. Keating, 'Perception of Numerical Invariance in Neonates', Child Development, 54.3 (1983), 695-701 <https://doi.org/ 10.2307/1130057> [accessed 10 January 2016]

Butterworth, Brian, The Mathematical Brain (London: Macmillan, 1999)

Campbell, Lyle, and Verónica María Grondona, eds., The Indigenous Languages of South America. A Comprehensive Guide (Berlin: Mouton de Gruyter, 2012)

Dehaene, Stanislas, Véronique Izard, Elizabeth Spelke, and Pierre Pica, 'Log or Linear? Distinct Intuitions of the Number Scale in Western and Amazonian Indigene Cultures', Science, 320.5880 (2008), 1217-1220 <https://doi.org/10.1126/science.1156540> [accessed 10 January 2016]

Dietrich, Wolf, 'O tronco tupi e as suas famílias de línguas. Classificação e esboço tipológico', in O Português e o Tupi no Brasil, ed. by Wolf Dietrich and Volker Noll (São Paulo: Editora Contexto, 2010), pp. 9-26

Everett, Daniel L., 'Cultural Constraints on Grammar and Cognition in Pirahã: Another Look at the Design Features of Human Language', Current Anthropology, 46 (2005), 621-646 <https://doi.org/10.1086/431525> [accessed 10 January 2016] 
Frank, Michael C., Daniel L. Everett, Evelina Fedorenko, and Edward Gibson, 'Number as a Cognitive Technology: Evidence from Pirahã Language and Cognition', Cognition, 108 (2008), 819-824 <https://doi.org/10.1016/j.cognition.2008.04.007> [accessed 15 January 2016]

Gallistel, C. R., and Rochel Gelman, 'Preverbal and Verbal Counting and Computation', Cognition, 44 (1992), 43-74 <https://doi.org/10.1016/0010-0277(92)90050-R> [accessed 10 March 2015]

Gordon, Peter, 'Numerical Cognition without Words: Evidence from Amazonia', Science, 306.5695 (2004), 496-499 <https://doi.org/10.1126/science.1094492> [accessed 10 March 2015]

Green, Diana, 'O sistema numérico da língua palikúr', Boletim do Museu Paraense Emílio Goeldi, Série Antropologia e Linguística (1994) <http://www.pnglanguages.org/ americas/brasil/publcns/ling/PortPLNB.pdf> [accessed 24 July 2016]

—_, 'Diferenças entre termos numéricos em algumas línguas indígenas do Brasil', Boletim do Museu Paraense Emílio Goeldi, Série Antropologia e Linguística (1997) <http:// www.unifal-mg.edu.br/matematica/files/file/ANDREA/Historia/ termos\%20numericos\%20indigenas\%20brasil.pdf> [accessed 24 July 2016] Hornborg, Alf, 'Ethnogenesis, Regional Integration, and Ecology in Prehistoric Amazonia: Toward a System Perspective', Current Anthropology, 46.4 (2005), 589-607 <https:// doi.org/10.1086/431530> [accessed 24 July 2016]

Hurford, James R., 'Languages Treat 1-4 Specially', Mind \& Language, 16 (2001), 69-75 <https://doi.org/10.1111/1468-0017.00157> [accessed 24 July 2016] Izard, Véronique, Pierre Pica, Elizabeth Spelke, and Stanislas Dehaene, 'Exact Equality and Successor Function: Two Key Concepts on the Path towards Understanding Exact Numbers', Philosophical Psychology, 21 (2008), 491-491 <https://doi.org/ 10.1080/09515080802285354> [accessed 24 July 2016] 
Matsuzawa, Tetsuro, 'Use of Numbers by a Chimpanzee', Nature, 315 (1985), 57-59 <https:// doi.org/10.1038/315057a0> [accessed 24 July 2016]

Müller, Ana, and Luciana Storto, and Thiago Coutinho-Silva, 'Number and the Count-Mass Distinction in Karitiana', University of British Columbia Papers in Linguistics - UBCWPL 19: Proceedings of the Eleventh Workshop on Structure and Constituency in Languages of the Americas (2006), 122-135

Nimuendajú, Curt, 'The Mura and Pirahã', in Handbook of South American Indians, ed. by Julian H. Steward (Washington: Smithsonian Institution, 1948), pp. 255-269

Núñez, Rafael, Kensy Cooperrider, and Jürg Wassmann, 'Number Concepts without Number Lines in an Indigenous Group of Papua New Guinea', PLoS One, 7 (2012), e35662e35662 <https://doi.org/10.1371/journal.pone.0035662> [accessed 15 March 2015]

Núñez, Rafael E., 'No Innate Number Line in the Human Brain', Journal of Cross-Cultural Psychology, 42 (2011), 651-668 <https://doi.org/10.1177/0022022111406097> [accessed 15 March 2015]

Pica, Pierre, and Alain Lecomte, 'Theoretical Implications of the Study of Numbers and Numerals in Mundurucu', Philosophical Psychology, 21 (2008), 507-522 <https:// doi.org/10.1080/09515080802285461> [accessed 15 March 2015]

Pica, Pierre, Cathy Lemer, Véronique Izard, and Stanislas Dehaene, 'Exact and Approximate Arithmetic in an Amazonian Indigene Group', Science, 306.5695 (2004), 499-503 <https://doi.org/10.1126/science.1102085> [accessed 15 March 2015]

Rodrigues, Aryon Dall'Igna, and Ana Suelly Arruda Câmara Cabral, 'Tupían', in The Indigenous Languages of South America: A Comprehensive Guide, ed. by Campbell, Lyle, and Verónica Grondona (Berlin: De Gruyter Mouton, 2012), pp. 495-574

Sarnecka, Barbara W., and Susan Carey, 'How Counting Represents Number: What Children Must Learn and When They Learn It', Cognition, 108 (2008), 662-674 <https://doi.org/ 10.1016/j.cognition.2008.05.007> [accessed 15 March 2015] 
Wassmann, Jürg, and P. Dasen, 'Yupno Number System and Counting', Journal of Cross-

Cultural Psychology, 25 (1994), 78-94 <https://doi.org/10.1177/0022022194251005> [accessed 15 March 2015]

Xu, F., and E. S. Spelke, 'Large Number Discrimination in 6-Month-Old Infants', Cognition, 74 (2000), B1-11 <https://doi.org/10.1016/S0010-0277(99)00066-9> [accessed 15 March 2015] 